\title{
Anmeldelser
}

skrevet igennem. De mange gentagelser skærer i øjnene. Hensigtserklæringer og essays byder sig til, og bogen bliver noget ujævn og torso-præget. Flere af de fremlagte essays er vredet for tæat omkring de bærende teser, hvorfor de ikke helt kommer op at flyve. De bliver for illustrerende, selvom det hverken er uinteressant at læse Schanz' fortolkning af Karl Poppers historieteori eller af Reinhardt Kosellecks tanker om vore tids-, rums- og epokebegreber. Nogle af de tidligere bøger fra idéhistorikerens hånd forekom strammere både i komposition, stil og i tanke. Jeg tæenker bl.a hér ikke mindst på Refleksion og balance. Refleksioner over metafysik og modernitet (Århus, 1990).

Endvidere kunne Forlaget Modtryk godt anskaffe sig et andet or-ddeli-ngspr-ogr-am.

Steen Nepper Larsen

\section{Ordet som tankens krop}

Ole Fogh Kirkeby: Ordenestid.Fragmenter til en sirlig filosofi, Det lille Forlag, 1996, 112 sider, kr. 140,-

$*$

Den tyske filosof Manfred Frank holdt i 1990 tre forelæsninger om filosofiens stil på Princeton Universitet i USA. Han bestemte stil som et sprogligt fænomen, og havdede, at selvom sproget almengør og begreberne er fællesgods, så er den individuelle stil i filosofien distinkt og umulig at eftergøre, når den er noget værd. Stilens mysterium består $i$, at den - selvom den principielt er ikke-meddelelig, unik og begrebsløs - faktisk kan forstås af andre, og at den altid vil blive fortolket forskelligt. Den individuelle stil lader sig ikke oversætte uden tab og ikke referere uden overgreb. En filosofisk stil følger ikke mekaniske sprogregler, og den er ikke en udvortes kladedragt på en tanke eller en genstand, der søger en beskyttende og reprasenterende "hud". Stilen er ikke til at adskille fra filosofiens substans. Det retoriske og det indholdsmæssige flyder ind i hinanden. En filosofisk stil ryster konventionens koder, mens den giver os et indblik i skribentens ejendommelighed og særegenhed. Verden bringes til et sprogligt udtryk, der ikke efterlader verden eller indvånerne i denne uberørt af denne skabelsesproces.

Stringens og stilhed

Ole Fogh Kirkebys lille nye bog har filo- 


\section{Anmeldelser}

sofisk stil i den Frank'ske forstand. Kirkeby (f.1947), dr.phil. på afhandlingen Begivenhed og kropstanke. En fanomenologiskhermeneutisk analyse (Forlaget Modtryk, Århus, 1994) og lektor på Handelshøjskolen i København, har samlet 70 gådefulde og dragende aforistisk-essayiske tekststykker. De sirlige fragmenter jager et sprog hinsides klichéen, på kanten af det uudsigelige. De ønsker "at ordene i deres timelighed kunne overgive en almenhed, som den personlige erfaring ikke uden videre ejer", skriver Kirkeby i sit forord. Der er en summende stilhed, en tænksom langsomhed over fragmenterne. Stilhed, ro, sommer, en svalende regn, blomsterst $\varnothing v$, svalereder, toner fra en violin og hengemte loftsrum. Længsler, håb, sol og højt til himlen.

Fantastisk er historien om den seksårige dreng på det rødsorte gulvtæppe i bedsteforxldrenes lejlighed i Skive. Englen Gabriel har afsat 22 minutter til at spørge ham om, hvad han vil være. Han forsøger sig med: "Jeg vil være stærk som en elefant", "Præst", "Lystfisker". Gabriel er ikke tilfreds med disse svar, og drengens $\varnothing$ jne glider febrilsk og søgende hen over bogryggene på reolerne. "Jeg vil være dansk idrætshistorie-r", "Jeg vil være Værker", "Jeg vil være Fremad". Englen gabte. "Du er en kedelig klient", sagde han. "Seksuel lykke", råbte drengen $i$ ekstase og for at vække den sure engel. "Jeg skal være i Toronto om $4 \mathrm{mi}$ nutter", sagde Gabriel, og drengen forstod den fine antydning. "Jeg vil være 'Hvem, Hvad, Hvor. 1952!'", sagde han fortvivlet. Gabriel var tilfreds: "Javel! Men stryg '1952'. Det er all right! Og så skal vi have det her mindst tre gange ved du." "Hvem, Hvad, Hvor. Hvem, Hvad, Hvor. Hvem, Hvad, Hvor!" "O.K.", sagde Gabriel og var off til Canada.

\section{At spise 'llakager'}

Det gælder om at fravriste døden og livet betydning. Det drejer sig om at komme til eksistens blandt de mystiske ting, der på én gang er tavse og mulige at åbne med det sprog, der på sin vis allerede bebor dem. "Det ord, der elsker tingene, er hos dem, fordi det er blevet glemt dér. Den, der bruger ordet 'solsikke' vil således ikke huskes som en talende, men vil viskes ud i tingens og landskabets tjeneste. /.../Han agerer da magisk på et støvs vegne..." For Kirkeby er det "en fejl i eksistensen selv, at døden findes". Mens livet leves, er det også en udfordring ikke at stivne i et dødt sprog. "Vi er dukker af kød og blod, hvis bestemmelse det er at måtte mime til en stemme, der kommer fra en andens mund". Som motto har Kirkeby valgt et citat af Platon: "Kun guderne behøver ikke at filosofere". Filosofien er forundringens og egensindighedens talerør. Med en dramatisk formulering: "... det man forstår alt for godt er uden tvivl noget, der altid breder sig ud fra dødens sted."

Som barn funderede Kirkeby over betydningen af ordet "Lakage". Han byggede paladser af mening op over det. "For mig sad ...menneskene med sabeltigerhoveder, i urtidsnatten ved sært hede bål og spiste disse 'lækager', kager bagt af blodet fra meget lette, lyse og sårbare skabninger. Skabninger som elverfolk." For ham var ord ikke blot 


\section{Anmeldelser}

instrumenter til at give en kendt verden navne, ej heller var ord blot ydre slør over verden. "...vi står målløse over for det faktum, at ord kan forløse", skriver han i en kærlighedserklæring til sprogets skabende kraft.

Kirkeby ønsker at overskride dualismerne mellem sansning og sprog, mellem bevidsthed og krop, mellem bevidsthed og verden. Det er ikke mindst dette ambitiøse fillosofiske forehavende, der tvinger ham ud i at tage livtag med aforismens krævende form. Hans filosofi tangerer et litteræert univers: "Sprogets krop og sansningens krop vil hver vare sin egen. Men jo mere de forsøger herpå, desto mere bruser deres falles blod." Sproget giver os sansningen, hævder Kirkeby; men sansningen kan kvalificere sproget, når det kører i tomgang. At Kirkeby ikke er en ren jublende sprogoptimist fremgår af følgende billedrige tristesse, der samtidig kan læses som en sensibel programmatisk erklæring: "Ordene i helvede er varme og tætte, bløde og salige som tøjhunde, men der er ingen børn til dem. Ordene i helvede er som valmuer på brakmarker. Ingen ser dem det eneste år, de blomstrer. / . . / . . værst lider de ord, der er udstoppede, konserverede, forstenede. De ord, hvis skæbne det er altid at måtte betyde det samme. Og de, der mener at vide, at der herigennem er ydet ordene en særlig gunst, glemmer, at de har mistet det for ord mest dyrebare, fornemmelsen for tid."

\section{Kirkebys fornemmelse for tid og nuancer}

Med disse vovestykker skriver Kirkeby sig ind $\mathrm{i}$ en ædel fillosofisk tradition. Arthur
Schopenhauers aforismer til livsvisdom, Friedrich Nietzsches sylespidse tekststykker, Ernst Blochs utopiindvarslende "Spor", Theodor W.Adornos melankolsk-kritiske Minima Moralia, Walter Benjamins fragmenter \& ensrettede gader og Ludwig Wittgensteins mange tankebenzinerende paragraffer på små papirlapper lever med i bogen som frugtbare inspirationskilder. Helligåndens sted er kroppen, skriver Kirkeby et sted, mens han søger logi under den åbne himmel, i sine egne tanker. Hér ånder han gennem de allestedsnærværende fænomenologiske tanker, gjort af Martin Heidegger og Maurice Merleau-Ponty. Der opstår et "mellemk $\varnothing d^{\prime \prime}$ i spillet mellem Kirkebys kropstanker og traditionens krop. I begyndelsen af det fjerde af bogens fem afsnit, "Mellemkødet", hedder det: "Verden ånder, banker, bevæger sig, fordi vi er denne verden, netop deri at den har taget bolig i os." Men de fremmede ting i verden skal først overtales, lokkes til at give svar. De skal åbnes og komme til verden i stemthedens sprog, skriver han. Bedst går det, når han ikke lader syntaksen gå helt i stykker og ikke bevidst dyrker de fikse ordspil, og når han undlader at lade litterære greb være blotte illustrationer af fænomenologisk-filosofiske pointer. Der er stærke billeder i Kirkebys tænkning og skrift: "...den, der vil bringe ånd til tanke, må ikke forvente, at de ikke kopulerer. Sengetøjet bliver helt sikkert både krøllet og plettet". Bedst går det, når han undlader at betvinge stoffet med sine aforistiske konstruktioner, når han lytter til og lader dets fremmedhed flyde i sirlige - på én gang strålende og minutiøse - tekstmønstre. 


\section{Anmeldelser}

Ifølge Kirkeby undrer Gud sig over os. "Han længes efter at se, hvem vi er". Han er en allestedsnærværende tilhører til sine egne skabningers forunderlige jordiske liv og drømme. Jeg undrer mig over, hvordan Kirkebys messianske drøm skal tage sig ud, når menneskets og verdens hud bliver identiske, og når Paradisets autentiske sprog virkeliggøres. Han forestiller sig sågar, at Gud vil tage sproget tilbage fra menneskene, når vi har lært at tale det rigtigt. Så må vi tie, og den fø̆r så tavse Gud kan atter tale. Men som læser behøver man jo ikke partout at hylde Kirkebys ny-romantiske og for det meste såre profane evangelium for at nyde de smukke fragmenter.

Med denne bog fortjener Kirkeby at få et egentligt gennembrud som filosof i Danmark. Han refererer ikke blot andres meninger. Han ikke bare udforsker et sprog og afsøger en genre, han fornyer sproget og giver kroppen, erindringen og sansningen fylde.

Steen Nepper Larsen

\section{Europaisk identitet}

Åke Daun: Den europeiska identiteten, Stockholm: Rabén \& Sjögren 1992, 212 sider, 222,- SEK.

$$
\text { * }
$$

Turbulensen i Europa har givet sig udslag i en stigende interesse for det nationale (se Slagmark nr. 19) og for de kulturelle forskelle. I begyndelsen af $80^{\prime}$ erne lavede man en stor europæisk holdningsunders $ø$ gelse (EVSSG), og med baggrund i dels denne, dels i en unders $\emptyset$ gelse blandt studerende og interviews med italiensk gifte svenske kvinder, har etnografen Åke Daun skrevet en bog om svensk og italiensk mentalitet og identitet. Målet med undersøgelsen er at kunne sige noget om "den europæiske identitet" $i$ et EU-perspektiv for derigennem at diskutere farerne eller fordelene for svensk kultur ved medlemskabet. Bogen er en spæendende påpegning af, hvad der tillægges værdi i Sverige og Italien, hele tiden med et udblik til de $\emptyset$ vrige europæiske lande. I et letløbende sprog bliver den svenske kulturelle homogenitet sammenlignet med den italienske mangfoldighed beskrevet; forholdet til familie, venner, autoriteter mv. unders $\emptyset$ ges, og konklusionen bliver - måske ikke specielt overraskende: "Svenskarnas genom EG ökade exponering för andra europeiska kulturer skall alltså inte i första hand betraktas som en ny 'konkurrenssituation', där svenskar kan tänkas välja utländska sedvänjor och grundvärderingar framför de blå-gula motsvarigheterna. Kulturer för- 